\title{
Determination of Residues of Chlorpyrifos and Its Oxygen Analog in Dates
}

\author{
Sameeh A. MANSOUR* \\ Plant Protection Research Division, Ministry of Agriculture, Iraq
}

(Received April 23, 1985)

\begin{abstract}
Residues of chlorpyrifos (O,O-diethyl-O-3,5,6-trichloro-2-pyridyl phosphorothioate) and its oxygen analog (O,O-diethyl-O-3,5,6-trichloro-2-pyridyl phosphate) were determined in dates following the application of Dursban ${ }^{\circledR}$ on palm trees by a gas chromatographic method. Residues of chlorpyrifos decreased sharply within 2 weeks after application, but detectable amounts remained up to 8 weeks. The oxygen analog of chlorpyrifos seemed to be more persistent than chlorpyrifos itself. To keep fruits clean from exessive contamination by chlorpyrifos, the shortest waiting period of 8 weeks between insecticide application and fruit harvest is recommended.
\end{abstract}

\section{INTRODUCTION}

Chlorpyrifos (Dursban ${ }^{\circledR}, O, O$-diethyl-O-3,5,6trichloro-2-pyridyl phosphorothioate) is a promising insecticide which is active against a wide spectrum of insect pests. ${ }^{1)}$

Among promising insecticides, chlorpyrifos has been evaluated for the control of some insect pests of dates in palm orchards in Iraq (e.g. Ommatissus binotatus FIEB. and Batrachedra amydraula MEYR.). A valid recommendation with any pesticide should take in consideration the residue data in edible plants at least, which might be associated with the use of such a pesticide under the local environmental conditions. So, the aim of the present investigation is to determine the residues of chlorpyrifos and its oxygen analog (O,O-diethyl-O-3,5,6-trichloro-2-pyridyl phosphate) in dates following the application of Dursban on palm trees.

\section{MATERIALS AND METHODS}

\section{Special Reagents}

Chlorpyrifos and its oxygen analog, analyti-

* Present address: National Research Centre, Dokki, Cairo, Egypt. cal reference standards, were obtained from Dow Chemical Co., Midland, U.S.A. Silica gel $60,70 / 230$ mesh (ASTM, Merck) was reactivated before use by heating overnight at $110^{\circ} \mathrm{C}$ in an electric oven. Solvents used were of reagent grades and redistilled in glass.

\section{Field Application and Sampling}

Trials were carried out in a palm orchard at Abu-Ghraib, Baghdad, Iraq. Palm trees were sprayed with a commercial formulation of Dursban $(40.8 \% \mathrm{EC})$ at a rate of $245 \mathrm{~g}$ a.i./ donum (or $980 \mathrm{~g}$ a.i./ha) with high pressure ground sprayers on June 12, 1979 (shortly after fruiting and infestation). Samples from both treated and control plots were taken 1 , 15, 29, 43, 57, 71 and 85 days after application and stored at $-12^{\circ} \mathrm{C}$ until analyzed.

\section{Extraction and Cleanup}

Prior to extraction, stones were removed from dates and $50 \mathrm{~g}$ subsamples (ca. 8-25 fruits $/ 50 \mathrm{~g}$, depending on the date of sampling) were taken for analyses. Extraction and cleanup of chlorpyrifos and its oxygen analog were accomplished according to the method described previously ${ }^{2)}$ after a slight modification in the cleanup stage. In the original 
Table 1 Elution pattern of chlorpyrifos and its oxygen analog on a silica gel column chromatography eluted with $120 \mathrm{ml}$ and $100 \mathrm{ml}$ of benzene and acetone, respectively.

\begin{tabular}{|c|c|c|c|c|c|}
\hline \multirow{2}{*}{$\begin{array}{l}\text { Benzene } \\
\text { fractions }^{a} \text { ) }\end{array}$} & \multicolumn{2}{|c|}{ Recovered (C) } & \multirow{2}{*}{$\begin{array}{c}\text { Acetone } \\
\text { fractions }\end{array}$} & \multicolumn{2}{|c|}{ Recovered (COA) } \\
\hline & $\mu \mathrm{g}$ & $\%$ & & $\mu \mathrm{g}$ & $\%$ \\
\hline$f_{1}$ & 5.4 & 10.8 & $f_{1}$ & 4.8 & 9.6 \\
\hline $\mathrm{f}_{2}$ & 40.8 & 80.0 & $\mathrm{f}_{2}$ & 32.2 & 64.4 \\
\hline $\mathrm{f}_{3}$ & 1.4 & 2.8 & $\mathrm{f}_{3}$ & 11.5 & 23.0 \\
\hline $\mathrm{f}_{4}$ & 1.2 & 2.4 & $\mathrm{f}_{4}$ & 0.0 & 0.0 \\
\hline$f_{5}$ & 1.0 & 2.0 & $f_{5}$ & 0.0 & 0.0 \\
\hline $\mathrm{f}_{6}$ & 0.0 & 0.0 & & & \\
\hline Total & 49.0 & 98.0 & Total & 48.5 & 97.0 \\
\hline Added & 50.0 & & Added & 50.0 & \\
\hline
\end{tabular}

a) Each fraction represents $20 \mathrm{ml}$ aliquots collected subsequently from the column and analyzed by $\mathrm{GC}$ for chlorpyrifos (C) and its oxygen analog (COA).

method, benzene-sample extract is cleaned-up on a silica gel column using $90 \mathrm{ml}$ of benzene. The first $20 \mathrm{ml}$ of eluate is discarded and the next $70 \mathrm{ml}$ is collected for chlorpyrifos analysis. Thereafter, the column is eluted with $60 \mathrm{ml}$ of acetone to separate the oxygen analog.

In the present study, the column $(2.5 \times 50$ $\mathrm{cm}$ ) was firstly eluted with $100 \mathrm{ml}$ of benzene and collected all for chlorpyrifos analysis. Then, the column was eluted with acetone as described in the original method. The elution pattern of chlorpyrifos and its oxygen analog on the silica gel column is represented by Table 1.

\section{Gas Chromatographic $(G C)$ Analyses}

GC analyses were performed on a PerkinElmer Model 3920 instrument equipped with a thermionic detector (TID-Rb Br) and a $6 \mathrm{ft} \times 1 / 4$ in o.d. glass column packed with $5 \%$ OV-17 on 80/100 mesh Gas Chrom Q. Gas flow rates were 30,100 and $40 \mathrm{ml} / \mathrm{min}$ for nitrogen, air and hydrogen, respectively. The temperature was $220^{\circ} \mathrm{C}$ at column, injector and detector. Under these conditions, the retention times $(R t)$ for chlorpyrifos and its oxygen analog were $4 \mathrm{~min} 54 \mathrm{sec}$ and $4 \mathrm{~min} 18 \mathrm{sec}$, respectively. Peak heights obtained from the injection of extracts of unknown samples were compared with appropriate standards to calculate the residues.

\section{Thin-layer Chromatographic (TLC) Anal- yses}

TLC was performed on $20 \times 20 \mathrm{~cm}$ glass plates coated with a $0.3 \mathrm{~mm}$-thick layer of silica gel DGF (Riedel-De-Haën AG, Hannover). Different concentrations of pure materials were prepared (in benzene), spotted on the silica gel plates and developed in benzene+ ethyl acetate $(9+1 ; \mathrm{v} / \mathrm{v})$. Spots were examined under a UV lamp $(254 \mathrm{~nm})$. Under these conditions, $R f$ values were 0.97 and 0.36 for chlorpyrifos and its oxygen analog, respectively. The detection limits for these compounds were $0.5 \mu \mathrm{g}$ and $0.2 \mu \mathrm{g}$, respectively. Benzene and/or acetone extracts remained after GC analyses were concentrated more $(c a .5 \mathrm{ml})$, and $50 \mu \mathrm{l}$ portions were spotted on the silica gel layers. Spots appearing after development were compared with those of corresponding authentic standards for identification.

\section{RESULTS AND DISCUSSION}

Although several gas chromatographic methods have been published for chlorpyrifos analysis, ${ }^{3-5)}$ few methods were published for the analysis of chlorpyrifos and its oxygen ana$\log { }^{2)}$ In the latter method, ${ }^{2)}$ detection of the analyzed compounds is achieved by a flame photometric detector. In the present study, a thermionic detector was used. Both types of detectors are quite sensitive to phosphorus. Determination limit for chlorpyrifos and its oxygen analog, in the present study, was 
Table 2 Per cent recovery of chlorpyrifos and its oxygen analog from dates at various levels of fortification.

\begin{tabular}{|c|c|c|c|c|c|c|c|}
\hline \multirow{2}{*}{ Compounds } & \multicolumn{6}{|c|}{ Fortification, ppm } & \multirow{2}{*}{ Av. } \\
\hline & 0.01 & 0.05 & 0.1 & 0.5 & 1.0 & 2.0 & \\
\hline Chlorpyrifos & 90.2 & 94.3 & 95.0 & 102.3 & 88.2 & 89.0 & $93.1 \%$ \\
\hline Oxygen analog & 78.5 & 85.3 & 83.1 & 91.7 & 88.0 & 76.8 & $83.9 \%$ \\
\hline
\end{tabular}

N.B. Each recovery value represents an average of 2 analyses.

Table 3 Residues of chlorpyrifos and its oxygen analog in dates at different time intervals following spraying of Dursban on palm trees.

\begin{tabular}{|c|c|c|c|}
\hline \multirow{2}{*}{$\begin{array}{l}\text { Date of } \\
\text { sampling }\end{array}$} & \multirow{2}{*}{$\begin{array}{l}\text { Days after } \\
\text { application }\end{array}$} & \multicolumn{2}{|c|}{ Residues, a) ppm } \\
\hline & & $\begin{array}{l}\text { Chlor- } \\
\text { pyrifos }\end{array}$ & $\begin{array}{l}\text { Oxygen } \\
\text { analog }\end{array}$ \\
\hline $13 / 6 / 79$ & 1 & 1.28 & $\mathrm{ND}$ \\
\hline $27 / 6$ & 15 & 0.20 & 0.50 \\
\hline $11 / 7$ & 29 & 0.05 & 0.32 \\
\hline $25 / 7$ & 43 & 0.03 & 0.30 \\
\hline $8 / 8$ & 57 & 0.01 & 0.21 \\
\hline $22 / 8$ & 71 & $\mathrm{ND}$ & 0.15 \\
\hline $5 / 9$ & 85 & $\mathrm{ND}$ & 0.10 \\
\hline 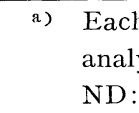 & $\begin{array}{l}\text { value represe } \\
\text { es. } \\
\text { Jot detected. }\end{array}$ & an av & se of 3 \\
\hline
\end{tabular}

found to be $0.01 \mathrm{ppm}$ and $0.05 \mathrm{ppm}$, respectively. Total recovery of the analytical method was satisfactory as shown in Table 2. On the other hand, TLC confirmed GC results concerning the presence of chlorpyrifos in benzene extracts of treated date samples as well as the oxygen analog in the acetone extracts.

Residues of chlorpyrifos and its oxygen analog in dates, at different time intervals after the application of Dursban, are presented in Table 3. Concentrations of chlorpyrifos decreased sharply within 2 weeks after the application. Thereafter, it remained at a low level up to 8 weeks after the application. Concentration of the oxygen analog reached 0.5 ppm 15 days after the application, then decreased slowly all through the season. This behavior may indicate that the oxygen analog was more persistent than the parent compound. Morever, by comparing the residues of both compounds (Table 3), one could conclude that other degradation products may be as- sociated with the application of Dursban on palm trees. Studies of metabolism of chlorpyrifos in plants, previously investigated, $\left.{ }^{6}\right)$ support the above-mentioned conclusion. Furthermore, it has been also reported ${ }^{6)}$ that chlorpyrifos is not absorbed into plants, but it accumulates on their surfaces where it decomposes by ultraviolet light. This may interpret the rapid dissipation of chlorpyrifos from dates, as shown in the present study.

To determine the safety of chlorpyrifos application on palm trees, the data presented in Table 3 indicate that a waiting period of 8 weeks after application should elapse before the fruit is harvested to get its chlorpyrifos concentration of $0.01 \mathrm{ppm}$ or less. After 8 weeks dates can be harvested nearly free from chlorpyrifos. Dates in Iraq are usually harvested during the first middle of August. This may lead to suggest the safety of chlorpyrifos residues in dates.

Unfortunately, no recommendations concerning the maximum permissible residue limit for chlorpyrifos in dates are yet available. There are recommendations for other crops such as cauliflower, red cabbage and potatoes in which $0.01 \mathrm{ppm}$ of chlorpyrifos is considered a maximum permissible residue limit by $\mathrm{FAO} / \mathrm{WHO}^{7}$. Even if we apply the $\mathrm{FAO} /$ WHO recommendation to dates, this will support the safety of chlorpyrifos residues in dates, provided that the dates should be harvested not before 8 weeks after the insecticide is applied on palm trees.

It has to be noted that $\mathrm{FAO} / \mathrm{WHO}$ recommendations excluded the oxygen analog of chlorpyrifos from terminal residues to be determined for regulatory purposes. This may be based on that residue and metabolism studies on other crops showed low persistency of the 
compound as compared with the mother one. Results of the present study may denote a special case on the dates. So if residues of the oxygen analog is also taken into the account, the situation would be completely different.

\section{ACKNOWLEDGEMENTS}

The author thanks Mrs. Intsar M. Nassif, Laboratory of Pesticides, Plant Protection Research Division, Abu-Ghraib, Baghdad for her assistance in the field experiments. Also, thanks to Dow Chemical Co. for supporting the analytical reference standards used in this study.

\section{REFERENCES}

1) E. E. Kenaga, W. K. Whitney, J. L. Hardy \& A. E. Doty: J. Econ. Entomol. 58, 1043 (1965)

2) M. C. Bowman \& M. J. Beroza: J. Agric. Food Chem. 15, 651 (1967)

3) J. R. Rice \& H. J. Dishburger: J. Agric. Food Chem. 16, 867 (1968)

4) L. M. Hunt, B. N. Gilbert \& J. C. Schlinke: $J$. Agric. Food Chem. 17, 1166 (1969)

5) M. E. Düsch, W. E. Westlake \& F. A. Gunther:
J. Agric. Food Chem. 18, 178 (1970)

6) G. N. Smith, B. S. Watson \& F. S. Fischer: $J$. Agric. Food Chem. 15, 870 (1967)

7) Anonymous: "Pesticide Residues in Food1977," FAO Plant Production and Protection Paper, 10 Rev., 1978

\section{要 約}

\section{ナツメャシ果実中のクロルピリホスとそのオキ} ソ体の残留分析

Sameeh A. Mansour

クロルピリホスをナツメヤシに散布後，本薬剤とその オキソ体の果実中での残留量を熱イオン検出器を装着し たガスクロマトグラフにより経時的に定量した。クロル ピリホスの残留量は 2 週間後には急速に減少している が，8週間後までな特低濃度で検出される，一方，才キ ソ体は残留性が高く，12週間後でも検出される．乙たが ってナツメヤシの収獲は, オキソ体の残留を問題としな い場合でも，クロルピリホス散布後少なくとも 8 週間経 過してから行なわれるべきであると考える。 